UDK 621.397

V.I. MAGRO

Oles Honchar Dnipro National University

S.V. PLAKSIN

Institute of Transport Systems and Technologies of the National Academy of Sciences of Ukraine

V.O. SVYATOSHENKO

National Technical University "Dnipro Polytechnic"

\title{
INVESTIGATION OF INFORMATION NETWORK LOADING IN THE CONDITIONS OF REMOTE EDUCATION AND REMOTE MONITORING
}

The method of estimating the bandwidth of communication channels and routing of Internet packets in the conditions of distance learning is considered. The research of media service platforms Microsoft Teams, Google Zoom and Skype was performed. A feature of the method is a combination of direct and indirect methods of estimating the bandwidth of communication channels. The application of this methodology makes it possible to evaluate existing market solutions for the implementation of distance education. This allows us to conclude on the feasibility of using the above services for distance learning. As a result, such a study helps to assess the congestion of channels and the effectiveness of remote monitoring of remote objects when the time delay in the delivery of information should not exceed a certain value. The results of the experiment showed that in general the considered platforms are very similar in the mode of conversation using only voice traffic. Bitrate in this case ranges from 100-130 Kbit/s. There is a significant difference between the platforms during the video traffic session. The differences between the platforms in the bitrate for this case are more than 90\% (in some cases more than 100\%). The study showed that the workload of the Internet channel on weekdays increased after ten $o^{\prime}$ clock in the afternoon. The Microsoft Teams platform provides the best video image quality. There are no differences between the platforms in terms of sound quality. General recommendations for organizing an online $T V$ broadcast are as follows: for voice traffic, you can choose any of the proposed platforms, due to the fact that the difference in their characteristics is insignificant it's better to use Google Zoom to organize video communication; it's best to choose the Microsoft Teams media platform to organize a screen demonstration session. Studies have made it possible to assess the load that occurs during a communication session. The results of the experiment showed that the Google Zoom media platform, with the same quality of communication, creates fewer loads on the main Internet channels. The technical result obtained in this work is the creation of tools for selecting the optimal media platform for remote communication.

Keywords: bandwidth of the Internet communication channel, media service platform, communication session, total bitrate, network load.

B.I. МАГРО

Дніпровський національний університет імені Олеся Гончара

С.В. ПЛАКСІН Інститут транспортних систем і технологій «Трансмаг» Національної академії наук України

В.О. СВЯТОШЕНКО

Національний технічний університет «Дніпровська політехніка»

\section{ДОСЛІДЖЕННЯ ЗАВАНТАЖЕННЯ ІНФОРМАЦІЙНОЇ МЕРЕЖІ В УМОВАХ ДИСТАНЦІЙНОЇ ОСВІТИ І ДИСТАНЦЙНОГО МОНІТОРИНГУ}

Розглянута методика оцінювання пропускної спроможності каналів зв'язку $i$ маршрутизації інтернет-пакетів в умовах дистанційного навчання. Виконано дослідження медіа сервісних платформ Microsoft Teams, Google Zoom ma Skype. Особливістю методики є поєднання прямих і непрямих методів оцінювання пропускної спроможності каналів зв'язку. Застосування даної методики надає змогу провести оцінку існуючих на ринку рішень для реалізації дистанційної освіти. Це дозволяє зробити висновок щуодо доцільності використання описаних вище сервісів для дистанційного навчання. В підсумку таке дослідження допомагає оцінити завантаженість каналів та ефективність роботи дистанційного моніторингу віддалених об'єктів коли часова затримка в доставиі інформації має суттеве значення. Результати експерименту показали, щз в цілому розглянуті платформи дуже схожі в режимі розмови з використанням тільки голосового трафіку. Бітрейт в цььому випадку коливається в діапазоні 100-130 Kбіт/с. Суттєва розбіжність між платформами спостерігається під час сеансу зв'язку з використанням відео трафіку. Відмінності між платформами в бітрейті для иього випадку 
складають більше 90\% (в окремих випадках понад 100\%). Дослідження показало, щчо заванженість інтернет-каналу в будні дні збільшувалась після десятої години дня. Платформа Microsoft Teams забезпечує найкращу якість відео зображення. За якістю звуку не відзначено відмінностей між платформами. Загальні рекомендації при організації он-лайн телевізійної трансляиї полягають в наступному: для голосового трафіку можна обрати будь-яку з запропонованих платформ, через те щзо розбіжність їх характеристик незначна; для організації відео зв'язку доиільніше використовувати сервіс Google Zоот; для організаиії сеансу зв'язку з демонстрацією екрану краще всього обрати медіа платформу Microsoft Teams. Проведені дослідження дозволили оиінити навантаження яке виникає під час сеансу зв'язку. Результати експерименту показали, щзо медіа платформа Google Zоот при рівній якості зв'язку створює менше навантаження на магістральні інтернет-канали. Технічним результатом отриманим в даній роботі є створення інструментарію для вибору оптимальної медіа платформи для організації дистаниійного зв'язку.

Ключові слова: пропускна здатність інтернет-каналу зв'язку, медіа сервісна платформа, сеанс зв'язку, загальний бітрейт, навантаження на мережу.

В.И. МАГРО

Днипровский национальный университет имени Олеся Гончара

С.В. ПЛАКСИН

Институт транспортных систем и технологий «Трансмаг» Национальной академии наук Украины

В.О. СВЯТОШЕНКО

Национальный технический университет «Днипровская политехника»

\section{ИССЛЕДОВАНИЕ ЗАГРУЗКИ ИНФОРМАЦИОННОЙ СЕТИ В УСЛОВИЯХ ДИСТАНЦИОННОГО ОБРАЗОВАНИЯ И ДИСТАНЦИОННОГО МОНИТОРИНГА}

Рассмотрена методика оценки пропускной способности каналов связи и маршрутизаџии интернет-пакетов в условиях дистанционного обучения. Выполнены исследования медиа сервисных платформ Microsoft Teams, Google Zoom и Skyре. Особенностью методики является сочетание прямых и косвенных методов оценки пропускной способности каналов связи. Применение данной методики дает возможность провести оценку существующих на рынке решений для реализации дистанционного образования. Это позволяет сделать вывод о целесообразности использования описанных выме сервисов для дистанционного обучения. В итоге такое исследование помогает оценить загруженность каналов и эффективность работы дистанционного мониторинга удаленных объектов, когда временная задержка в доставке информации не должна превышать определенную величину. Результать эксперимента показали, что в целом рассмотренные платформы очень похожи в режиме разговора с использованием только голосового трафика. Битрейт в этом случае колеблется в диапазоне 100-130 Кбит/с. Существенное расхождение между платформами наблюдается во время сеанса связи с использованием видео трафика. Различия между платформами в битрейте для этого случая составляют более 90\% (в отдельных случаях более 100\%). Исследование показало, что загруженность интернет-канала в будние дни увеличивалось после десяти часов дня. Платформа Microsoft Teams обеспечивает наилучшее качество видео изображения. По качеству звука не отмечено различий между платформами. Общие рекомендации при организации онлайн телевизионной трансляции заключаются 8 следующем: для голосового трафика можно выбрать любую из предложенных платформ, потому что различие их характеристик незначительно; для организачии видеосвязи иелесообразнее использовать сервис Google Zоот; для организации сеанса связи с демонстрацией экрана лучше всего выбрать медиа платформу Microsoft Teams. Проведенные исследования позволили оченить нагрузку, которая возникает во время сеанса связи. Результаты эксперимента показали, что медиа платформа Goоgle Zoот при равном качестве связи создает меньшую нагрузку на магистральные интернет-каналь. Техническим результатом, который получен в данной работе, является создание инструментария для выбора оптимальной медиа платформы для организации дистанционной связи.

Ключевые слова: пропускная способность интернет-канала связи, медиа сервисная платформа, сеанс связи, общий битрейт, нагрузка на сеть.

\section{Formulation of the problem}

An important issue that arises during the organization of distance learning is the choice of platform on which it will take place. An important parameter is the ability to 
minimize the load on the communication channels while maintaining high quality. Another important feature is the bandwidth of the communication channel.

Now the educational process takes place with the help of information networks. Every day, thousands of students and teachers use media services such as Microsoft Teams, Google Zoom and Skype to conduct online lectures or to communicate with teachers and classmates. This download of the information network may affect the remote monitoring system of remote objects.

Another important feature is the bandwidth of the communication channel. It can be limited by a number of factors, such as the remoteness of the server you are connecting to.

\section{Analysis of recent research and publications}

When organizing any online broadcast, you should pay attention to the value of the time delay in the delivery of packets $[1,2]$. In most cases, it should not exceed a certain value. The amount of delay is determined by the properties of the media service platform and the characteristics of the communication channel.

Traffic scheduling is a key factor in ensuring time synchronization. Therefore, realtime communication in distributed systems is difficult. Poor planning can lead to a high degree of concatenation between the configuration of an individual data stream and the configuration of global (network-wide) traffic [3]. Therefore, forecasting network traffic is an important task [4]. Operators of cellular networks plan network traffic especially carefully in order to ensure network performance and quality of service (QoS) [5].

Recently, special attention has been paid to the study of public networks. In particular, the effectiveness of video streaming for public safety is investigated [6]. In this case, the delay in the delivery of information should be minimal.

In the general case, the planning of the parameters of the communication channel should be performed taking into account the requirements for the quality of service [7]. The development of distance education makes it necessary to predict the use of bandwidth in order to minimize time delays in the delivery of packets when remotely monitoring important production processes.

The above factors determine the relevance of this work.

\section{The aim of the study}

The purpose of the study is to assess the load of information channels in terms of distance learning. To achieve this aim, it is necessary to investigate the most common media service platforms in distance education: Microsoft Teams, Google Zoom and Skype. It is necessary to solve the following tasks: to develop an algorithm and conduct an experiment to determine the bandwidth of the Internet channel; analyze the routing method and bandwidth of the communication channel; compare media service platforms.

\section{Presentation of the main material of the study}

To collect information about the bandwidth of the communication channel, the iperf3 program was used. The collection of statistical information on the bandwidth of the Internet channel and the preparation of data for analysis included the following steps:

1. Creation of an Excel table to save data on the bandwidth of the Internet channel (Tab. 1)

2. Checking the bandwidth of the channel by connecting to the server iperf.volia.net (Kyiv);

3. Copying data to the clipboard and pasting it into an Excel spreadsheet; the data was divided into seven columns (time of the experiment), which in turn were divided into three groups: "min" (minimum value of bitrate), "ave" (average value of bitrate) and "max" (maximum value of bitrate);

4. Three hours later, the experiment was repeated; 
5. The "ave" value from the Excel spreadsheet was used to build diagrams that show the change in channel bandwidth during the day.

Table 1

Bandwidth of the Internet channel

\begin{tabular}{|c|c|c|c|c|c|c|c|c|c|c|c|c|c|c|c|c|c|c|c|c|c|}
\hline \multirow[b]{2}{*}{ Date } & \multicolumn{3}{|c|}{$7: 00$} & \multicolumn{3}{|c|}{$10: 00$} & \multicolumn{3}{|c|}{$13: 00$} & \multicolumn{3}{|c|}{$16: 00$} & \multicolumn{3}{|c|}{$19: 00$} & \multicolumn{3}{|c|}{$22: 00$} & \multicolumn{3}{|c|}{$0: 00$} \\
\hline & min & ave & $\max$ & min & ave & $\max$ & $\min$ & ave & $\max$ & min & ave & $\max$ & min & ave & $\max$ & in & ave & $\max$ & nin & ave & $\max$ \\
\hline 05.11 & 12,4 & 6,6 & 4,1 & 5,9 & 5,3 & 5,7 & 23,7 & 31 & 3,9 & 3,4 & 24,5 & 43,7 & 15,2 & 25,6 & 4,4 & 24,3 & 30,4 & 8,9 & 25,7 & 3,6 & 50 \\
\hline 3.11 & 5,2 & 3,4 & 56,7 & 13,3 & 23,1 & 33,8 & 9,3 & 21,5 & 33,1 & 10,4 & 19,6 & 27,2 & 11,3 & 20,6 & 32,9 & 18,6 & 28,1 & 39,5 & 24,3 & 30,4 & 9 \\
\hline 7.11 & 65,1 & 84,4 & 96,2 & 72,5 & 80 & 94,8 & 60,3 & 77,2 & 89,9 & 68,8 & 71,2 & 80,8 & 66,9 & 72,5 & 83,2 & 22,1 & 56 & 78,2 & 19,2 & 46,5 & 64,2 \\
\hline 3.11 & 8,6 & 3,2 & 94,9 & 24,2 & 74,8 & 90,7 & 63,6 & 84,5 & 6,3 & 46 & 71,6 & 87,4 & 2,1 & 58,1 & 78,5 & 44,6 & 51,4 & 4,1 & 15,2 & 46,6 & 1 \\
\hline 09.11 & 12,9 & 20,3 & 47,4 & 17,2 & 22,8 & 34,9 & 19,2 & 23,1 & 31,8 & 14,6 & 25,7 & 30 & 13,8 & 33,8 & 48,3 & 2,28 & 30,4 & 38,6 & 23,7 & 31 & 51,1 \\
\hline 10.11 & 4,3 & 3,2 & 3,8 & 17,4 & 3,3 & 53,1 & 29,1 & 38,8 & 1,1 & 1,9 & 31,2 & 41,0 & 6,6 & 28,3 & 62,2 & 21,7 & 42,3 & 55,5 & 12,3 & 35,7 & 6,2 \\
\hline 11.11 & 20,2 & 24 & 6 & 8,7 & 40,6 & 79,8 & 7,2 & 25,9 & 36,4 & 1,9 & 22,6 & 53,1 & 5,9 & 28,2 & 40,9 & 16,7 & 26 & 35,5 & 19,5 & 32,7 & 40 \\
\hline 12.11 & 23,4 & 10 & 60,3 & 24,4 & 1,9 & 4,4 & 20 & 35,3 & 52,1 & 4,3 & 22,4 & 36,6 & 13,4 & 2 & 39,4 & 9,09 & 19,6 & 7 & 9 & 8 & 47,6 \\
\hline 13.11 & 1,6 & 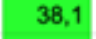 & 58,9 & 9,8 & 40,6 & 73,2 & 26,3 & 35,2 & 61 & 12,3 & 28,3 & 52,1 & 13,8 & 31,3 & 47 & 1,2 & 37,9 & 72,3 & 21,7 & 42,3 & 55,5 \\
\hline 14.11 & 77,9 & 81,9 & 93 & 6,5 & 70,2 & 96,8 & 69,1 & 79,6 & 99,3 & 47,2 & 64,3 & 75,2 & 52,6 & 69,3 & 80,9 & 3,3 & 33,5 & 106 & 1,1 & 39,6 & 89 \\
\hline 15.11 & 2,8 & 62,8 & 100 & 24,2 & 74,8 & 90,7 & 63,6 & 84,5 & 96,3 & 46 & 71,6 & 82,1 & 59,4 & 77,4 & 78,5 & 44,6 & 51,4 & 74,1 & 15,2 & 46,6 & 72,1 \\
\hline 16.11 & 12,4 & 26,6 & 64,1 & 15,9 & 35,3 & 55,7 & 23,7 & 31 & 51,1 & 11,9 & 31,2 & 41,9 & 6,6 & 28,3 & 62,2 & 21,7 & 42,3 & 55,5 & 12,3 & 35,7 & 56,2 \\
\hline
\end{tabular}

During the experiment, an Excel file was formed with statistical information to analyze the bandwidth of the Internet channel. More than 70 experiments were carried out to collect information for the implementation of the actions specified in paragraph 2 . The research was conducted on the basis of the Internet provider Uranus.

Microsoft Teams, Google Zoom and Skype were chosen to experiment with services that provide the ability to communicate on the network. To connect the subscribers, the "client-server" communication scheme was used. The chosen communication scheme allows the experiment to be carried out under the conditions of an ordinary user.

Statistical information was collected using Wireshark. The functionality that Wireshark provides is very similar to that of tcpdump, but Wireshark has a graphical user interface and much more sorting and filtering capabilities. The program allows the user to view all traffic passing through the network in real time. The collection of statistical information about the bandwidth of the Internet channel and the preparation of data for analysis included the following steps:

1. Preparation for recording a communication session in the Wireshark program, namely, disabling all possible processes on the computer that could interfere with the purity of the experiment;

2. Start of recording a session in Wireshark;

3. Simulation of one of the possible conversation options;

4. Wireshark captures Internet packets that arrive at the receiver ports;

5. Plotting inbound / outbound traffic.

During the experiment, files with the extension ".pcapng" were formed with recorded information about the communication session for video traffic analysis. A study of three different options for communication between users based on the media service platforms Microsoft Teams, Google Zoom and Skype was carried out. During the analysis of the collected information about the bandwidth of the Internet channel, an Excel-table 1 was created, the data from which were used to construct table 2 .

Analysis of table 2 shows that on weekdays in the period from 13: 00-19: 00 there is the greatest decrease in channel capacity (Fig. 1). On weekends, on the contrary, the minimum values of throughput are observed in the period from 19:00 (Fig. 2). Most online classes are held from 10:00, during the period when communication channels are already loaded. 
Table 2

Generalized communication channel bandwidth data

\begin{tabular}{|c|c|c|c|c|c|c|c|}
\hline Date & $7: 00$ & $10: 00$ & $13: 00$ & $16: 00$ & $19: 00$ & $22: 00$ & $0: 00$ \\
\hline 05.11 .20 & 26.6 & 35.3 & 31.0 & 24.5 & 25.6 & 30.4 & 33.6 \\
\hline 06.11 .20 & 23.4 & 23,1 & 21.5 & 19.6 & 20.6 & 28.1 & 30.4 \\
\hline 07.11 .20 & 84.4 & 80.0 & 77.2 & 71.2 & 72.5 & 56.0 & 46.5 \\
\hline 08.11 .20 & 68.2 & 74.8 & 84.5 & 71.6 & 58.1 & 51.4 & 46.6 \\
\hline 09.11 .20 & 20.3 & 22.8 & 23.1 & 25.7 & 33.8 & 30.4 & 31.0 \\
\hline 10.11 .20 & 23.2 & 33.3 & 38.8 & 31.2 & 28.3 & 42.3 & 35.7 \\
\hline 11.11 .20 & 24.0 & 40.6 & 25.9 & 22.6 & 28.2 & 26.0 & 32.7 \\
\hline 12.11 .20 & 41.9 & 41.9 & 35.3 & 22.4 & 26.6 & 19.6 & 26.8 \\
\hline 13.11 .20 & 38.1 & 40.6 & 35.2 & 28.3 & 31.3 & 37.9 & 42.3 \\
\hline 14.11 .20 & 81.9 & 70.2 & 79.6 & 64.3 & 69.3 & 33.5 & 39.6 \\
\hline 15.11 .20 & 62.8 & 74.8 & 84.5 & 71.6 & 77.4 & 51.4 & 46.6 \\
\hline 16.11 .20 & 26.6 & 35.3 & 31.0 & 31.2 & 28.3 & 42.3 & 35.7 \\
\hline
\end{tabular}

In the course of research on the capture of Internet packages, a server has been installed through which data is exchanged in communication services. In fig. 3 shows the path of packets, from user to server, on the example of the service Microsoft Teams. Iperf3 allows you to find out the delay of Internet packets and the path of packets. That is, through which IP addresses packets pass to the final server of information exchange (tab. 3). During a communication session, the delay to the server, which is located in Dublin, is $88 \mathrm{~ms}$. The starting point for sending packages is the city of Dnipro. Internet packages travel on trunk channels through Kyiv and then across Europe to Dublin.

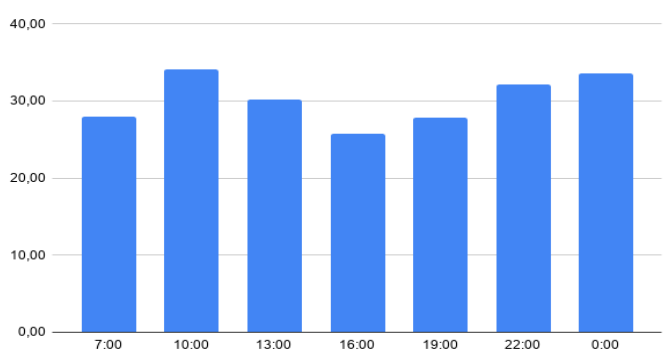

Fig. 1. Average value of channel bandwidth on a weekday (Mbps)

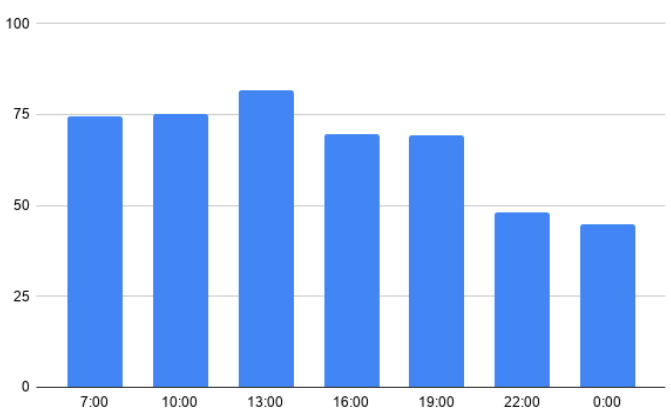

Fig. 2. Average value of channel bandwidth on the weekend (Mbps)

The characteristics of media service platforms for distance education are compared. The considered media platforms transmitted information using the UDP protocol. Based on the results of the collected information, comparative tables were created. Table 4 provides information about the communication session using only voice traffic. It can be seen that all three media service platforms have almost the same results; the divergence of their characteristics is minimal. The best value of the bit rate in the Internet channel was provided by the Google Zoom service $-840 \mathrm{Kbytes} / \mathrm{s}$. Table 5 shows general information when simulating a webcam session. The results obtained differ significantly. It can be seen that the 
Microsoft Teams service provided a load on the Internet channel twice as much as on other platforms. It should be noted that the quality of the video picture was different in different services. Comparison of video service platforms during the screen demonstration is shown in table. 2. Skype service creates a load on the communication channel by $60-145 \%$ more than other services.

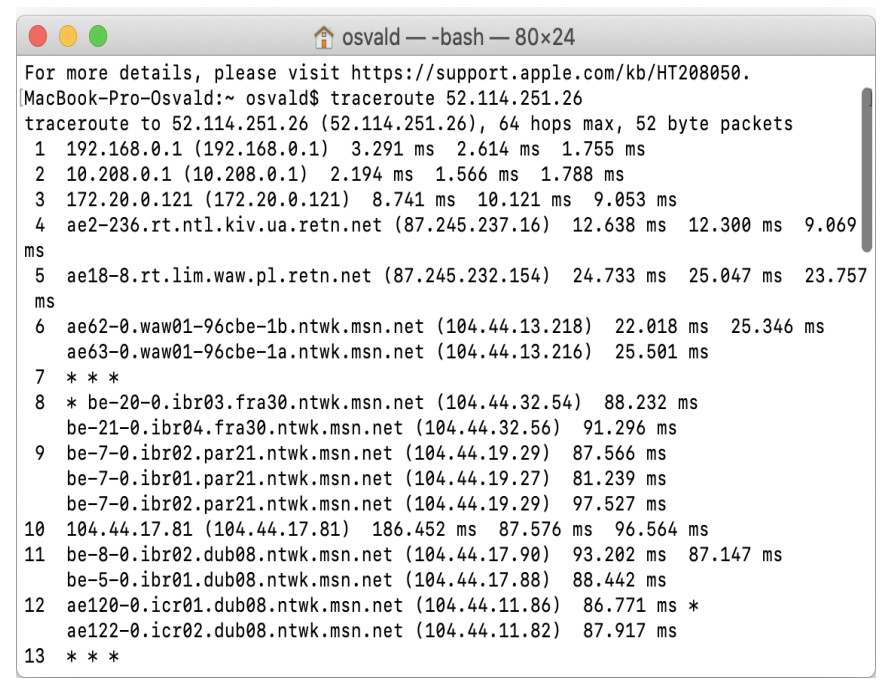

Fig. 3. IP addresses of servers through which the communication session takes place

Table 3

Location of servers

\begin{tabular}{|c|c|c|c|c|c|}
\hline No. & Server & Server location & No. & Server & Server location \\
\hline 1 & 87.245 .237 .16 & Ukraine, Kyiv & 8 & 104.44 .19 .27 & France, Paris \\
\hline 2 & 87.245 .232 .154 & Poland, Warsaw & 9 & 104.44 .19 .29 & France, Paris \\
\hline 3 & 104.44 .13 .218 & Poland, Warsaw & 10 & 104.44 .17 .81 & Great Britain, London \\
\hline 4 & 104.44 .13 .216 & Poland, Warsaw & 11 & 104.44 .17 .90 & Great Britain, London \\
\hline 5 & 104.44 .32 .54 & Germany, Frankfurt & 12 & 104.44 .17 .88 & Great Britain, London \\
\hline 6 & 104.44 .32 .56 & Germany, Frankfurt & 13 & 104.44 .11 .86 & Ireland, Dublin \\
\hline 7 & 104.44 .19 .29 & France, Paris & 14 & 104.44 .11 .82 & Ireland, Dublin \\
\hline
\end{tabular}

Table 4

Information about the communication session using only voice traffic

\begin{tabular}{|c|c|c|c|}
\hline Media service platform & $\begin{array}{c}\text { Average bitrate, } \\
\text { Kbit/s }\end{array}$ & $\begin{array}{c}\text { The amount of information transmitted } \\
\text { per minute of conversation, kbytes }\end{array}$ & $\begin{array}{c}\text { Number of erroneous } \\
\text { Internet packages }\end{array}$ \\
\hline Microsoft Teams & 127 & 900 & 0 \\
\hline Google Zoom & 118 & 840 & 0 \\
\hline Skype & 135 & 960 & 0 \\
\hline
\end{tabular}

Table 5

Information when simulating a webcam session

\begin{tabular}{|c|c|c|c|}
\hline Media service platform & $\begin{array}{c}\text { Average bitrate, } \\
\text { Mbit/s }\end{array}$ & $\begin{array}{c}\text { The amount of information transmitted } \\
\text { per minute of conversation, Mbytes }\end{array}$ & $\begin{array}{c}\text { Number of erroneous } \\
\text { Internet packages }\end{array}$ \\
\hline Microsoft Teams & 2,8 & 21,5 & 0 \\
\hline Google Zoom & 1,4 & 10,2 & 0 \\
\hline Skype & 1,7 & 13,0 & 0 \\
\hline
\end{tabular}

Table 6

Comparison of video service platforms during the screen demonstration

\begin{tabular}{|c|c|c|c|}
\hline Media service platform & $\begin{array}{c}\text { Average bitrate, } \\
\text { Mbit/s }\end{array}$ & $\begin{array}{c}\text { The amount of information transmitted } \\
\text { per minute of conversation, Mbytes }\end{array}$ & $\begin{array}{c}\text { Number of erroneous } \\
\text { Internet packages }\end{array}$ \\
\hline Microsoft Teams & 0,4 & 3,4 & 0 \\
\hline Google Zoom & 0,3 & 2,2 & 0 \\
\hline
\end{tabular}




\begin{tabular}{|c|c|c|c|}
\hline Skype & 0,7 & 5,4 & 0 \\
\hline
\end{tabular}

\section{Conclusions}

The proposed technique allows estimating both the bandwidth of the Internet channel and the load on the telecommunications network. A feature of the technique is the combination of direct and indirect methods for assessing the throughput. The application of this methodology allows for a preliminary assessment of the existing infrastructure.

The studies carried out made it possible to estimate the total bitrate and the load that it causes on communication channels when organizing distance education based on the media service platforms Microsoft Teams, Google Zoom and Skype. The results of the experiment showed that, in general, the platforms considered are very similar in the talk mode using only voice traffic. The bitrate in this case is in the range of 100-130 kbps.

A significant difference in performance between platforms is observed during a communication session using video traffic. On average, the difference between platforms is more than $90 \%$ (in some cases, more than $100 \%$ ).

General guidelines for organizing online television broadcasting are as follows:

- it is better to use the Google Zoom service to organize video communication;

- for a screen sharing session, it is best to choose the Microsoft Teams media platform.

The scientific novelty of the results obtained lies in the development of a methodology for choosing a media service for organizing distance learning. It consists in identifying the capacity of the platform for organizing student-teacher communication and assessing its components using a software package for fixing Internet packages and bandwidth.

The practical significance of the results obtained lies in the creation of tools for choosing the optimal media service platform. As a result, such a study helps to assess the congestion of channels and the effectiveness of remote monitoring of remote objects, when the time delay in the delivery of information should not exceed a certain value.

Prospects for further research are to use the proposed technical solution for the organization of distance learning in educational institutions under quarantine measures.

\section{Список використаної літератури}

1. Красовська Ю.О., Магро B.I. Впровадження цифрового телебачення DVB-T2 на 9 каналі в місті Дніпро. Радіоелектроніка, інформатика, управління. 2017. т.40. №1. C.7-15. DOI: 10.15588/1607-3274-2017-1-1.

2. Магро В.І., Святошенко В.О., Тимофеєв Д.С. Метод оцінки часу затримки в процесі потокового мовлення. Системи обробки інформації. 2019. Т.159. №4. С. 28-35. DOI: $10.30748 /$ soi.2019.159.03.

3. Falk J., Durr F., Rothermel K. Time-triggered traffic planning for data networks with conflict graphs. IEEE Real-Time and Embedded Technology and Applications Symposium (RTAS). 2020. pp. 124-136. DOI: 10.1109/RTAS48715.2020.00-12.

4. KuanHoong P., Tan I.K.T., Keong C.Y. Bittorrent network traffic forecasting with ARMA. International Journal of Computer Networks \& Communications (IJCNC). 2012. Vol. 4. No. 4. pp. 143-156. DOI: 10.5121/ijcnc.2012.4409.

5. Delgado D.L. J., Santiago J.M.R. Key performance indicators for QOS assessment in TETRA networks. International Journal of Mobile Network Communications \& Telematics (IJMNCT). 2013. Vol. 3. No. 6. pp. 1-18. DOI: 10.5121/ijmnct.2013.3601.

6. Ahmad R.W., Shan R., Khan A.R. An investigation of video communication over bandwidth limited public safety networks. Malaysian Journal of Computer Science. 2018. Vol. 31. No. 2. pp. 85-107. DOI: 10.22452/mjcs.vol31no2.1Pop. 
7. Balandin S.I., Mustafin N.A., Heyner A.P. Communication channel parameters planning under given requirements on the quality of network traffic service. SPIIRAS Proceedings. 2003. Issue 1. Vol. 3. SPb: SPIIRAS, 2003. pp. 235-246.

8. Aldhyani T.H.H., Joshi M.R. Intelligent time series model to predict bandwidth utilization. International Journal of Computer Science and Applications. 2017. Vol. 14 No. 2. pp. 130-141.

\section{References}

1. Krasovska, Y.O., \& Magro, V. I. (2017). Vprovadzhennya tsyfrovoho telebachennya DVB-T2 na 9 kanali v misti Dnipro. Radio Electronics, Computer Science, Control. 40, 1, 7-15. DOI: 10.15588/1607-3274-2017-1-1.

2. Magro, V.I., Svyatoshenko, V.O. \& Tymofeyev, D.S. (2019). Metod otsinky chasu zatrymky v protsesi potokovoho movlennya. Systemy obrobky informatsiyi. 159, 4, 2835. DOI: $10.30748 /$ soi.2019.159.03.

3. Falk, J., Durr, F., \& Rothermel, K. (2020). Time-triggered traffic planning for data networks with conflict graphs. IEEE Real-Time and Embedded Technology and Applications Symposium (RTAS). pp. 124-136. DOI: 10.1109/RTAS48715.2020.00-12.

4. KuanHoong, P., Tan, I.K.T., \& Keong C.Y. (2012). Bittorrent network traffic forecasting with ARMA. International Journal of Computer Networks \& Communications (IJCNC). 4, 4, 143-156. DOI: $10.5121 /$ ijcnc.2012.4409.

5. Delgado, D.L. J., \& Santiago, J.M.R. (2013). Key performance indicators for QOS assessment in TETRA networks. International Journal of Mobile Network Communications \& Telematics (IJMNCT). 3, 6, 1-18. DOI: 10.5121/ijmnct.2013.3601.

6. Ahmad, R.W., Shan, R., \& Khan, A.R. (2018). An investigation of video communication over bandwidth limited public safety networks. Malaysian Journal of Computer Science. 31, 2, 85-107. DOI: $10.22452 / \mathrm{mjcs} . v o l 31$ no2.1Pop.

7. Balandin, S.I., Mustafin, N.A., \& Heyner, A.P. (2003). Communication channel parameters planning under given requirements on the quality of network traffic service. SPIIRAS Proceedings. 1, 3, SPb: SPIIRAS, pp. 235-246.

8. Aldhyani, T.H.H. \& Joshi, M.R. (2017). Intelligent time series model to predict bandwidth utilization. International Journal of Computer Science and Applications. 14, $2,130-141$.

Магро Валерій Іванович - канд. фіз.-мат. наук, доцент, доцент кафедри прикладної радіофізики, електроніки та наномантріалів Дніпровського національного університету імені Олеся Гончара. E-mail: magrov@i.ua, ORCID: 0000-0003-4238-6733.

Плаксін Сергій Вікторович - доктор фіз.-мат. наук, старший науковий співробітник, завідувач відділу систем керування інституту транспортних систем i технологій «Трансмаг» Національної академії наук України. E-mail: svp@westainter.com, ORCID: 0000-0001-8302-0186.

Святошенко Володимир Олександрович - старший викладач Національного технічного університету «Дніпровська політехніка». E-mail: svyt22@gmail.com, ORCID: 0000-0003-4027-5706. 